УДК 342.9

DOI https://doi.org/10.32837/pyuv.v0i1(30).507

\author{
Д. О. Іицк \\ orcid.org/0000-0003-3052-3665 \\ кандидат юридичних наук, докторант \\ Науково-дослідного інституту публічного права
}

\title{
ДО ХАРАКТЕРИСТИКИ ПОВНОВАЖЕНЬ НАЦІОНАЛЬНОГО АНТИКОРУПЦІЙНОГО БЮРО УКРАЇНИ
}

Постановка проблеми. На Національне антикорупційного бюро України згідно ст. 1 Закону України «Про Національне антикорупційне бюро України» (далі - Бюро) покладаються функції попередження, виявлення, припинення, розслідування та розкриття корупційних правопорушень, віднесених до його підслідності, а також запобігання вчиненню нових. В реалізації своїх повноважень Бюро обмежене підслідністю корупційних правопорушень, проте названий Закон не визначає такої підслідності. Вона встановлюється нормами ч. 5 ст. 216 КПК України та охоплює деякі склади корупційних злочинів: злочини, вчинені певним колом суб'єктів; злочини, що мають значний обсяг предмета або обсяг завданої таким злочином шкоди.

У Пояснювальній записці до проєкту Закону України «Про систему спеціально уповноважених суб'єктів у сфері протидії корупції» зазначається, що підслідність справ Національного бюро визначено, виходячи 3 необхідності обмеження кількості справ, якими займатиметься новий орган, і зосередження його уваги на високопосадовій корупції та корупційних правопорушеннях, що завдають особливо великої шкоди захищеним законом інтересам. Це передбачає виключення зі сфери уваги нового спеціалізованого органу менш серйозних справ про корупцію та адміністративних корупційних правопорушень [1]. Проте такий підхід дістає певної критики у правовій літературі.

Стан дослідження. Окремі проблемні питання щодо функціонування Національного антикорупційного бюро України у своїх наукових працях розглядали Ю.І. Паршин, Ю.Г. Масікевич, О.В. Шестопалов, А.А. Негадайло, К.О. Сорока, I.О. Клочко, О.І. Добровольський, М.В. Цвік, В.А. Дем'янчук, В.В. Доненко, В.Д. Бабкін та багато інших. Втім недостатньо дослідженим є питання повноважень Національного антикорупційного бюро України, що є суттєвою прогалиною на теоретичному та практичному рівнях, адже саме повноваження Бюро мають забезпечити повноцінне виконання покладених на нього завдань.

Метою статті є надати характеристику повноваженням Національного антикорупційного бюро України.

Виклад основного матеріалу. Якщо проаналізувати зміст обов'язків Бюро, які передбачені ст. 16 вказаного Закону, то слід зазначити, що вони вказують саме на основні функції Бюро, виконання яких відбувається шляхом реалізації наданих Бюро прав та обов'язків. Повноваження Бюро найбільш повно розкриваються у правах та обов'язках, передбачених Законом України «Про Національне антикорупційного бюро України». Певні підходи до класифікації повноважень Антикорупційного бюро вже були розглянуті у правовій літературі.

На думку Р. Гречанюк, з огляду на права та обов'язки, якими наділене НАБУ, можна зробити висновок, що цей орган виконує три функції: 1) оперативно-розшукову; 2) досудового розслідування; 3) превентивну, що полягає у здійсненні інформаційно-аналітичної роботи з метою виявлення та усунення причин і умов, що сприяють вчиненню кримінальних правопорушень, віднесених до підслідності НАБУ [2, с. 43-44].

Проте автор вважає, що таких функцій більше. На основі аналізу обов'язків до основних напрямів діяльності Бюро можна віднести здійснення оперативно-розшукових заходів з метою попередження, виявлення, припинення та розкриття кримінальних правопорушень, віднесених законом до його підслідності, а також в оперативно-розшукових справах, витребуваних від інших правоохоронних органів; здійснення досудового розслідування кримінальних правопорушень, віднесених законом до його підслідності, а також проведення досудового розслідування інших кримінальних правопорушень у випадках, визначених законом; здійснення інформаційно-аналітичної роботи з метою виявлення та усунення причин і умов, які сприяють вчиненню кримінальних правопорушень, віднесених до підслідності Національного бюро, до цього напряму роботи Бюро доцільно віднести й звіт про свою діяльність в установленому порядку та інформування суспільства про результати своєї роботи; здійснення співпраці з іншими суб'єктами (з іноземними суб'єктами, іншими державними органами, органами місцевого самоврядування та іншими суб'єктами, а також співпраці з особами, які повідомляють про корупційні правопорушення) з метою виконання поставлених завдань; здійснення заходів, спрямованих на захист майнових інтересів держави у зв'язку з виявленням, припиненням, розслідуванням і розкриттям корупційних 
правопорушень, віднесених до його підслідності; здійснення заходів щодо забезпечення особистої безпеки працівників Національного бюро та інших визначених законом осіб, захист від протиправних посягань на осіб, які беруть участь у кримінальному судочинстві, у підслідних йому кримінальних правопорушеннях, в тому числі й шляхом дотримання умов конфіденційності та добровільності при співпраці з особами, які повідомляють про корупційні правопорушення.

Вказані напрями діяльності втілюються шляхом застосування певних правових інструментів, закріплених чинним законодавством. На основі аналізу положень ст. 17 можна зробити певну класифікацію таких прав:

1. Права, пов'язані із заведенням оперативно-розшукових справ та із забезпеченням провадження оперативно-розшукових та слідчих дій, зокрема заводити оперативно-розшукові справи на підставі постанови, що затверджується начальником відповідного підрозділу Національного бюро, та здійснювати на підставах і в порядку, установлених законом, гласні та негласні оперативно-розшукові заходи; на підставі відповідного рішення суду на строк до 10 діб опечатувати архіви, каси, приміщення (за винятком жилих) чи інші сховища, брати їх під охорону, а також вилучати предмети і документи в порядку, передбаченому Кримінальним процесуальним кодексом України; за пред'явлення службового посвідчення входити безперешкодно до державних органів, органів місцевого самоврядування та зони митного контролю, а за письмовим розпорядженням Директора Національного бюро або його заступника безперешкодно проходити до військових частин та установ, пунктів пропуску через державний кордон України; використовувати з подальшим відшкодуванням завданих збитків за транспортні засоби, які належать фізичним та юридичним особам (крім транспортних засобів дипломатичних, консульських та інших представництв іноземних держав і організацій, транспортних засобів спеціального призначення), для проїзду до місця події, припинення кримінального правопорушення, переслідування та затримання осіб, які підозрюються у їх вчиненні, доставлення до закладів охорони здоров'я осіб, які потребують екстреної медичної допомоги; у цілях оперативно-розшукової та слідчої діяльності створювати інформаційні системи та вести оперативний облік в обсязі і порядку, передбачених законодавством) [3].

2. Права, пов'язані з інформаційним забезпеченням оперативно-розшукової та досудово-слідчої діяльності Антикорупційного бюро:

- за рішенням Директора Національного бюро, погодженим із прокурором, витребовувати від інших правоохоронних органів оперативно-розшукові справи та кримінальні провадження, що стосуються кримінальних правопорушень, віднесених законом до підслідності Національного бюро, та інших кримінальних правопорушень, які не належать до його підслідності, але можуть бути використані з метою попередження, виявлення, припинення та розкриття кримінальних правопорушень, віднесених законом до його підслідності, або виявлення необгрунтованих активів та збору доказів їх необгрунтованості [3];

- витребовувати за рішенням керівника структурного підрозділу Національного бюро та одержувати в установленому закономпорядку у вказаному в запиті вигляді та формі від інших правоохоронних і державних органів, органів місцевого самоврядування, підприємств, установ, організацій інформацію, необхідну для виконання обов'язків Національного бюро, в тому числі відомості про майно, доходи, видатки, фінансові зобов'язання осіб, які ними декларуються у встановленому законом порядку, відомості про використання коштів Державного бюджету України, розпорядження державним або комунальним майном [3].

Національне бюро в порядку, визначеному законодавством, має безпосередній, в тому числі автоматизований, доступ до автоматизованих інформаційних і довідкових систем, реєстрів і банків даних, держателем (адміністратором) яких $€$ державні органи або органи місцевого самоврядування, користується державними, в тому числі урядовими, засобами зв'язку і комунікацій, мережами спеціального зв'язку та іншими технічними засобами; знайомитися в державних органах, органах місцевого самоврядування із документами та іншими матеріальними носіями інформації, необхідними для попередження, виявлення, припинення та розслідування кримінальних правопорушень, віднесених законом до підслідності Національного бюро, або виявлення необгрунтованих активів та збору доказів їх необгрунтованості, в тому числі такими, що містять інформацію з обмеженим доступом; на підставі рішення Директора Національного бюро або його заступника, погодженого з прокурором, отримувати від банків, депозитарних, фінансових та інших установ, підприємств та організацій незалежно від форми власності інформацію про операції, рахунки, вклади, правочини фізичних та юридичних осіб, яка необхідна для виконання обов'язків Національного бюро [4].

3. Координаційні права щодо залучення осіб, які не є працівниками Бюро, для впровадження оперативно-розшукової та досудово-слідчої діяльності: залучати на добровільній основі, в тому числі на договірних засадах, кваліфікованих спеціалістів та експертів, в тому числі іноземців, з будь-яких установ, організацій, контрольних і фінансових органів для забезпечення виконання повноважень Національного бюро, а також 
право за письмовим рішенням Директора Національного бюро або його заступника, погодженим із прокурором, створювати спільні слідчі групи, що включають оперативних та слідчих працівників; здійснювати правове співробітництво із компетентними органами іноземних держав, міжнародними організаціями 3 питань проведення оперативно-розшукової діяльності, досудового розслідування, виявлення необгрунтованих активів і збору доказів їх необгрунтованості на підставі законів і міжнародних договорів України [3].

4. Права, пов'язані із забезпеченням безпеки як працівників Бюро, так і інших осіб, які беруть участь в розслідуванні справ Бюро: видавати в разі наявності небезпеки для життя і здоров'я особам, взятим під захист, відповідно до законодавства зброю, спеціальні засоби індивідуального захисту та сповіщення про небезпеку; порушувати питання щодо створення спеціальних умов (у тому числі щодо засекречування перебування, здійснення заходів безпеки, поміщення в окремому приміщенні) в ізоляторах тимчасового тримання та установах попереднього ув'язнення для осіб, які співпрацюють із Національним бюро; зберігати, носити та застосовувати вогнепальну зброю і спеціальні засоби, а також застосовувати заходи фізичного впливу на підставах і в порядку, передбачених Законом України «Про Національну поліцію» [3].

5. Права, пов'язані із забезпеченням насамперед майнових інтересів держави у зв'язку з розслідуванням корупційних правопорушень: виступати як представник інтересів держави під час розгляду у закордонних юрисдикційних органах справ про розшук, арешт, конфіскацію та повернення в Україну відповідного майна, захист прав та інтересів держави з питань, які стосуються виконання обов'язків Національного бюро, а також залучати з цією метою юридичних радників, зокрема іноземних; вносити подання прокурору про звернення до суду з метою визнання недійсним правочину за наявності підстав, передбачених законом, а також право бути залученим за своєю заявою до таких справ як третя особа, яка не заявляє самостійних вимог щодо предмета спору).

Слід зазначити, що ця група прав існує вже без визнаного неконституційним права за наявності підстав, передбачених законом, подавати до суду позови про визнання недійсними угод у порядку, встановленому законодавством України [5]. При цьому, як було повідомлено в Центрі протидії корупції, це рішення може коштувати державі 7 млрд грн - на таку суму обраховуються вже розірвані з ініціативи НАБУ через суди угоди [6].

6. Права, пов'язані з виконанням Бюро завдань із попередження та запобігання вчиненню корупційних правопорушень, до них слід віднести право надсилати державним органам, органам місцевого самоврядування обов'язко- ві до розгляду пропозиції та рекомендації щодо усунення причин і умов, які сприяють вчиненню кримінальних правопорушень, віднесених до підслідності Національного бюро, а також отримувати від цих органів протягом 30 днів інформацію про розгляд таких пропозицій і рекомендацій [3]. Окремі автори виділяють так звані допоміжні функції, які реалізує Антикорупційне бюро, зокрема функції матеріального забезпечення, розвитку інфраструктури органу, управління персоналом, здійснення юридичних дій, зв'язки з громадськістю тощо [7, с. 87].

В якості висновку слід зазначити, що на основі розгляду повноважень Бюро можна виділити їх певні види, зокрема за напрямами їх реалізації: оперативно-розшукові; досудового розслідування; інформаційно-аналітичні; взаємодії, співробітництва та співпраці з іншими суб'єктами; захист майнових інтересів держави у зв'язку з виявленням, припиненням, розслідуванням і розкриттям корупційних правопорушень; забезпечення безпеки працівників Національного бюро та інших визначених законом осіб, які беруть участь у кримінальному судочинстві.

Слід також вказати на доцільність збільшення обсягу прав Бюро з реалізації завдання попередження та запобігання вчиненню корупційних правопорушень шляхом виконання обов'язку із здійснення інформаційно-аналітичної роботи з метою виявлення та усунення причин і умов, які сприяють вчиненню таких правопорушень.

Для якісного виконання Бюро завдань із попередження та запобігання вчиненню корупційних правопорушень необхідним є збільшення його повноважень щодо участі у нормотворчому процесі, а саме участі в розробці та удосконаленні нормативно-правових актів щодо попередження i боротьби з корупційними правопорушеннями. Під час реалізації своїх повноважень Бюро акумулює значну кількість інформації, яка слугує основою для проведення аналітичної роботи 3 виявлення причин, умов, інших обставин вияву корупційної поведінки в українському суспільстві. Доцільно було б безпосередньо серед прав Бюро вказати на його участь у розробці стратегії запобігання та боротьби з корупційними правопорушеннями, яке надано Національному агентству з питань запобігання корупції. Загалом Національне антикорупційного бюро України залишається тим органом, який при потенційних можливостях вдосконалення чинного законодавства для повноцінного виконання завдань із протидії корупційним правопорушенням недостатньо виконує свою роль.

Слід погодитися $з$ думкою Р. Гречанюк про те, що створення Національного антикорупційного бюро України не виправдало своєї мети - утворення єдиного спеціального антикорупційного органу, як це відбулося в багатьох країнах світу 
та передбачено міжнародними вимогами. Причиною цього авторка вважає те, що Закон України «Про Національне антикорупційне бюро України» значно обмежує повноваження цього органу, адже воно діє лише як орган боротьби з так званою високопосадовою корупцією, для якої характерний значний розмір предмета злочину. Виходом із цієї ситуації є передача Бюро функції щодо здійснення кримінального переслідування усіх корупційних правопорушень, забравши цю функцію в інших правоохоронних органів, розширивши повноваження Бюро [8, с. 46-47].

Висновки. Отже, вдосконалення правового регулювання повноважень Бюро може бути ключем до посилення боротьби з корупцією в Україні. Таке вдосконалення може відбуватися двома шляхами:

- збільшення обсягу повноважень Бюро, спрямованих на посилення його взаємодії з Національним агентством з питань запобігання корупції як із тим органом виконавчої влади, який забезпечує формування та реалізує державну антикорупційну політику, та 3 іншими владними суб'єктами, діяльність яких безпосередньо пов'язана 3 антикорупційними функціями;

- об'єднання повноважень таких органів як Національне агентство з питань запобігання корупції, Національне агентство України з питань виявлення, розшуку та управління активами, одержаними від корупційних та інших злочинів та Національне антикорупційне бюро України, що дозволить вирішити проблему дублювання функцій органів, які здійснюють боротьбу з корупцією, збільшити ефективність цієї боротьби, а також зменшити витрати державного бюджету. Цей шлях автор вважає більш раціональним.

\section{Iimepamypa}

1. Пояснювальна записка до проєкту Закону України «Про систему спеціально уповноважених суб'єктів у сфері протидії корупції» № 5085 від 16 вересня 2014 року [Електронний ресурс]. Режим доступу: http://w1.c1.rada.gov.ua/pls/zweb2/webproc4_1?pf3511= 52186.

2. Гречанюк Р.В. Функції і повноваження спеціальних антикорупційних органів України, Польщі та Молдови: Порівняльний аналіз. Науковий часопис Національної акаделії прокуратури України. 2015. № 2. C. 41-48.

3. Про Національне антикорупційне бюро України / Закон України від 14.10.2014 № 1698-VII. [Електронний ресурс]. Режим доступу: https://zakon.rada. gov.ua/laws/show/1698-18.

4. Про депозитарну систему України / Закон України від 06.07.2012 № 5178-VI.

5. Рішення Конституційного Суду України у справі за конституційною скаргою акціонерного товариства «Запорізький завод феросплавів» щодо відповідності Конституції України (конституційності) положення пункту 13 частини першої статті 17 Закону України «Про Національне антикорупційне бюро України» від 05 червня 2019 року № 4-p(II)/2019. Офіиійний вісник України 2019 р. № 53, с. 79, ст. 1850.

6. Конституційний Суд обмежив повноваження НАБУ на вимогу компанії Коломойського. https://biz.ligazakon.net/ua/news/186824 konstitutsyniysud-obmezhiv-povnovazhennya-nabu-na-vimogu-kompankolomoyskogo.

7. Комарова Ю.М. Адміністративно-правовий статус Національного антикорупційного бюро України :дис. канд. юрид. наук: 12.00.07. К., 2018. 229 с.

8. Гречанюк Р.В. Функції і повноваження спеціальних антикорупційних органів України, Польщі та Молдови: Порівняльний аналіз. Науковий часопис Національної академії прокуратури України, 2015. № 2. C. 41-48.

\section{Анотація}

Іщук Д. О. До характеристики повноважень Національного антикорупційного бюро України. - Стаття.

У статті на основі аналізу наукових поглядів вчених i норм чинного законодавства надано змістовну характеристику повноваженням Національного антикорупційного бюро України. Здійснено класифікацію обов'язків та прав Національного антикорупційного бюро України. Запропоновано шляхи вдосконалення правового регулювання повноважень Бюро, які можуть бути ключем до посилення боротьби з корупцією в Україні. 3'ясовано, що для якісного виконання Національним антикорупційним бюро України завдань із попередження та запобігання вчиненню корупційних правопорушень необхідним $є$ збільшення його повноважень щодо участі у нормотворчому процесі, а саме участі в розробці та удосконаленні нормативно-правових актів щодо попередження і боротьби з корупційними правопорушеннями.

Під час реалізації своїх повноважень Національне антикорупційне бюро України акумулює значну кількість інформації, яка слугує основою для проведення аналітичної роботи з виявлення причин, умов, інших обставин вияву корупційної поведінки в українському суспільстві. Доцільно було б безпосередньо серед прав Національного антикорупційного бюро України вказати на його участь у розробці стратегії запобігання та боротьби з корупційними правопорушеннями, яке надано Національному агентству з питань запобігання корупції. Зроблено висновок, що вдосконалення правового регулювання повноважень Бюро може бути ключем до посилення боротьби з корупцією в Україні. Таке вдосконалення може відбуватися двома шляхами: шляхом збільшення обсягу повноважень Бюро, спрямованих на посилення його взаємодії з Національним агентством $з$ питань запобігання корупції як із тим органом виконавчої влади, який забезпечує формування та реалізує державну антикорупційну політику, та з іншими владними суб'єктами, діяльність яких безпосередньо пов'язана 3 антикорупційними функціями; об'єднання повноважень таких органів як Національне агентство з питань запобігання корупції, Національне агентство України з питань виявлення, розшуку та управління активами, одержаними від корупційних та інших злочинів, та Національне антикорупційне бюро України, що дозволить вирішити проблему дублювання функцій органів, які здійснюють боротьбу з корупцією, збільшити ефективність цієї боротьби, а також зменшити витрати державного бюджету.

Ключові слова: повноваження, юридичні обов'язки, суб'єктивні права, Національне антикорупційне бюро України. 


\section{Summary}

Ishchuk D. O. To characterize the powers of the National Anti-Corruption Bureau of Ukraine. - Article.

In the article, based on the analysis of scientific views of scientists and norms of the current legislation, the substantive characterization of the powers of the National Anti-Corruption Bureau of Ukraine is given. The duties and rights of the National Anti-Corruption Bureau of Ukraine have been classified. Proposed ways to improve the legal regulation of the Bureau's mandate, which may be key to strengthening the fight against corruption in Ukraine. It is found out that in order to fulfill the tasks of prevention and prevention of corruption offenses by the National Anti-Corruption Bureau of Ukraine it is necessary to increase its powers to participate in the legislative-making process, namely to participate in the development and improvement of normative-legal acts on prevention and fight against corruption.

In the course of exercising its powers, the National Anti-Corruption Bureau of Ukraine accumulates a considerable amount of information, which serves as a basis for analytical work to identify the causes, conditions and other circumstances of corruption behavior in Ukrainian society. It would be advisable to indicate directly among the rights of the National Anti-Corruption Bureau of Ukraine its involvement in the development of a strategy for the prevention and fight against corruption offenses, which is now provided to the National Agency for the Prevention of Corruption. It is concluded that improving the legal regulation of the Bureau's mandate may be the key to strengthening the fight against corruption in Ukraine. Such improvement can be done in two ways: by increasing the powers of the Bureau aimed at enhancing its interaction with the National Anti-Corruption Agency as a body of executive power that provides for the formation and implementation of state anti-corruption policy, and with other subordinate authorities, the activities of which are directly related to anti-corruption functions; unifying the powers of bodies such as the National Agency for the Prevention of Corruption, the National Agency of Ukraine for the detection, search and management of assets obtained from corruption and other crimes, and the National Anti-Corruption Bureau of Ukraine, which will solve the problem of duplication of functions of bodies carrying out to fight corruption, to increase the effectiveness of this fight, and to reduce the expenditures of the state budget accordingly.

Key words: powers, legal obligations, subjective rights, National Anti-Corruption Bureau. 